\title{
A BALANCING ACT: MODERN EQUALITY VS TRADITIONAL NOBILITY IN TONGA
}

\author{
Tim René Salomon*
}

The article examines the treatment of commoners and nobles under the Tongan Constitution and ordinary legislation. This paper argues that Tonga fails to meet internationally acknowledged equality standards because "Tongan culture clashes head-on with basic human rights requirements". The article provides some suggestions how to achieve a balance between upholding Tongan culture and traditions and complying with internationally accepted equality standards.

\section{INTRODUCTION}

In 2006, riots in Nuku'alofa ${ }^{1}$ shocked the Tongan population and people all over the world with a connection to the Kingdom of Tonga. The seemingly sudden outburst of violence stands in contrast to the islands otherwise known as the "friendly Islands". ${ }^{2}$ However, Professor I F Helu foresaw such a development as early as 1992, when he stated at the Convention on Tongan Constitution and Democracy ${ }^{3}{ }^{4}$

If they are left to take their own course, there may be long periods where there are only a few insignificant changes taking place, but when real change does come, it will do so, more often than not, with violent and explosive fury, and even if desired goals are achieved, it will certainly effect extensive

* LLB, Bucerius Law School, Hamburg, Germany. The author is specialising in the field of public international law and European law. The author wishes to express his sincere gratitude to Annelen Micus, LLB; James Faulkner LLB, MA; Marion Struck-Garbe, Dipl. Sozialwirtin; Patisepa Helu; Melanie Piédavent; Julie McKee; Via Atiola and Benjamin Kuhn for their kind suggestions and encouragement.

1 Coverage at www.scoop.co.nz/stories/HL0611/S00331.htm (accessed 23 December 2008).

2 www.cia.gov/library/publications/the-world-factbook/geos/tn.html (accessed 15 December 2008).

3 Convention on Tongan Constitution and Democracy, Nuku'alofa, Tonga, 24-27 November 1992 [Constitutional Convention].

$4 \quad$ I F Helu "Why change and change what?" in Report on the Constitutional Convention (Nuku'alofa, 1992) 86 available at www.planet-tonga.com/HRDMT/Pdf_Files/Konivesio92.pdf (accessed 24 December 2008). 
destruction to property and lives and such social damage that would cost immense resources to redress. Both the French Revolution and the Bolshevik Revolution are examples of the lack of foresight and the absence of the will to dialogue and plan sociopolitical change.

Since the riots, the people of Tonga have been seeking a solution to issues that are now more pressing than ever. People's Representative (PR) Edwards among other PRs, who has recently been re-elected, is defending himself before the Tongan Supreme Court for his alleged participation in the riots, which mainly consisted of talking to the people he is representing. ${ }^{5}$ The crime he allegedly committed - sedition ${ }^{6}$ - includes speaking words that are expressive of the intention to excite disaffection against the King of Tonga or against the Parliament, the Legislative Assembly or the Judiciary in Tonga. ${ }^{7}$ The broad application of the sedition provision and its extremely vague wording ("disaffection") severely limits public expression of opinion and seems outdated. These charges are closely connected to the work of Clive Edwards and the conflict between the commoners and nobles, which is rooted in the perceived inequality between both.

This article will outline the legal differences between "nobles" and "commoners" and examine the justifiability of those distinctions under international law. It will show that the current Tongan system falls short of ensuring internationally acknowledged equality standards, due to the fact that "Tongan culture clashes head-on with basic human rights requirements". ${ }^{8}$ The Tongan Government and ultimately its monarch are under an obligation under international law to provide for equality among the citizens of Tonga. This article attempts to provide suggestions for the transitional period of the implementation of reforms as recently pronounced by the King. ${ }^{9}$

5 www.rnzi.com/pages/news.php?op=read\&id=38376 (accessed 15 of December 2008).

6 Tongan Criminal Offences Act arts 47 and 48 [TCOA].

7 Similar definitions can be traced back to the 1630s to 1640s: see Roger B Manning "The Origins of the Doctrine of Sedition" in Albion 12:2 (1980) 100-101, when it was used during the First English Civil War to silence separatists. See also Richard Overton An Alarum to the House of Lords against their Insolent Ursurpation of the Common Liberties (1646) 8. The punishment under Tongan law is a maximum of seven years imprisonment. In addition to the sentence, a conviction for sedition with a prison term of two or more years results in the deprivation of the offender's "right as a citizen" and of his right to hold an appointment in the public service and vote in an election according to Article 49 of the TCOA. It can only be hoped that the judiciary again upholds human rights, as Judge Finnegan stated: "It is not shown to my satisfaction that the accused actually said that ("the King is a dictator"). But if he did then, in their context those words can only mean, "the King is an authoritarian ruler who ignores my repeated requests for accountability by Himself and his Ministers"... if he said this, it appears to me to be the truth." King v Pohiva Supreme Court of Tonga (1998) cited in S Akilisi Pohiva "Media, Justice in Tonga" (2002) 8 Pacific Journalism Review 96, 100.

8 I F Helu Critical Essays - Cultural Perspectives from the South Seas (Journal of Pacific History, Canberra, 1999) 33.

9 Declaration from the Office of the Prime Minister Nuku'alofa (28 July 2008) available at www.scoop.co.nz/stories/WO0807/S00827.htm (accessed 24 December 2008). 
The first part of the article outlines privileges of nobles in Tongan domestic law. After this, the traditional concept of nobility in Tonga is then described to ascertain the origin of this inequality. The third part examines equality rights, their status in international law and Tonga's obligations. In conclusion, suggestions towards a solution are sought.

\section{INEQUALITY OF NOBLES AND COMMONERS IN TONGAN LEGISLATION}

The following section will show that there is unequal treatment of commoners and nobles under the current Tongan legislation. For the purposes of this article, the Constitution of Tonga is the main object of the examination. Article 3 of the Constitution is of central importance when focussing on equality and social structure. It proclaims:

There shall be but one law in Tonga for chiefs and commoners for non-Tongans and Tongans. No laws shall be enacted for one class and not for another class but the law shall be the same for all the people of this land.

Article 82, which used to give the Chief Justice the power to suspend laws inconsistent with the Constitution, was replaced in 1990 by the new article 82 declaring:

This Constitution is the supreme law of the Kingdom and if any other law is inconsistent with this

Constitution, that other law shall, to the extent of the inconsistency, be void.

In theory, this would mean that every piece of legislation that allows inequality between nobles and commoners is void and without any effect. However, the Constitution itself provides for such inequality. Article 32 regulates succession to the throne and establishes that "if there should be no lawful heir the King shall appoint his heir if the House of Nobles consent to it." This provision goes on to explicitly state that "the representatives of the people ... [have] no voice in the matter". Choosing the King or Queen in a monarchic system that assigns a significant amount of power to the monarch is a vital right, which carries enormous weight. Nobles also have the right under Article 32 to "choose by ballot some one of the chiefs whom they wish to succeed as King" if there is no heir to the Crown. The People's Representatives have no right of participation in this matter either. When read together with Articles 41, 49, 67 and 79, the legal effect of these provisions is that nobles can in certain circumstances determine the person who will become King, who then "is immune from impeachment under a charter that cannot be changed without his consent". ${ }^{10}$ This constitutes a severe distinction between nobles and commoners, granting nobles a significant advantage in power.

Article 60 of the Constitution stipulates:

10 Rev Siupeli Taliai "The Constitution of Tonga from a Christian perspective" in Report on the Constitutional Convention, above n 4, 82. 
There shall be elected by the nobles of the Kingdom from their number nine nobles as representatives of the nobles and there shall be elected by electors duly qualified nine representatives of the people.

This constitutes another distinction between nobles and commoners, although at first sight there is seemingly equal treatment between nobles and commoners. The unjustified equal treatment of situations that are inherently different can also amount to discrimination. Here the privilege of the nobles lies in the fact that they are granted a higher percentage of representatives compared to the common people, who, despite overwhelmingly outnumbering the nobles (33 is the total number of hereditary nobles electing their nine representatives, compared to around 119,000 commoners), ${ }^{11}$ are represented by an equal number of representatives.

Other examples for privileges of nobility are articles 67 and 71 . Article 67 is headed "Privilege of nobles" and gives only nobles the right to discuss or vote upon laws "relating to the King or the Royal Family or the titles and inheritances of the nobles." Article 71 excludes the participation of People's Representatives in trials judging over facts that allow depriving a "noble of his seat" in the Legislative Assembly.

Moreover, there is inequality concerning land distribution. Article 104 of the Constitution allows only nobles, titular chiefs or matapules (leaders of lower rank) to own hereditary estates. Sale of land is not permitted; however, hereditary estates can be leased. Although 16-year-old male Tongans are entitled to an allotment of land, ${ }^{12}$ they must in practice obtain the estate holder's consent before the application for a plot of land can be considered by the Minister of Lands. ${ }^{13}$ While this process may be comparatively easy for government-owned land most of which is, however, already occupied, it is more cumbersome for hereditary estates (tofi'a), which nobles own. ${ }^{14}$ In practice, the applicant has to prepare the way to the estate holder's consent with gifts and in some cases even money. ${ }^{15}$ Yet still the estate holder has the power of delaying the registration, which has been done in many cases for "reasons of power and personal advantage". ${ }^{16}$ This provision maintains the nobles as landlords over those who live on their estates. ${ }^{17}$ The different

11 Ibid, 83.

12 Tongan Land Act, s 43(1). Allocation to each qualified person has been impossible since 1981 due to land shortage. See Elizabeth Bott "Power and Rank in Tonga" (1981) 90(1) Journal of the Polynesian Society 7, 70 .

13 Report on the Constitutional Convention, above n 4, 157.

14 Tongan Land Act, s 9; Sione Latukefu "History of the Tongan Constitution" Report on the Constitutional Convention, above $\mathrm{n} 4$.

15 Ron Crocombe Land Tenure in the Pacific (Oxford University Press, Melbourne, 1971) 114.

16 Ibid.

17 Report on the Constitutional Convention, above n 4, 157. 
treatment of nobles and commoners regarding land ownership leads to severe inequalities between the two groups.

Furthermore, other legislation such as the Defamation Act (article 4 for nobles and other dignitaries and Article 5 for other persons) distinguish between nobles and commoners and award higher protection for nobles by introducing harsher sentences for defamation of such dignitaries. Thus, there are pronounced distinctions between nobles and commoners, even in the highest hierarchy of legislation. In order to explain these differences, regard has to be paid to the social organisation in Tonga and its historical origins.

\section{SOCIAL ORGANISATION IN TONGA}

\section{A Historical Theories on the Early Beginnings}

Many different theories claim to have found the answer to the heritage of the Polynesian people. It is safe to assume that the Polynesian people were skilful navigators and arrived on the islands from the west about 3,500 years ago. ${ }^{18}$ The theory argued by Williamson seems to be a wellfounded description of the origin of the current social organisation. ${ }^{19}$ Arriving on the islands, the social organisation of these survivors was divided in family groupings. ${ }^{20}$ As family units became larger, fissions shaped social organisation. Some groups became dominant over others through given factors such as unequal distribution of fertile lands and food-supply as well as through intergroup rivalry. Resulting from this process, the dominant group sought to maintain and strengthen their status by building alliances. Power became centralised in single persons - headmen of family units became chiefs. Through alliances an even higher social rank, head-chief, was formed. Consequently, the area controlled by one person gained in size. At the same time, social etiquette and forms of taboo arose in connection to the chiefs and they were associated to the godlike ancestors the people believed in. This elevated chiefs to a high political, spiritual and sacred position. Essentially, chiefs were seen as different beings to commoners: ${ }^{21}$

Pulotu was the place where the chiefs' souls went after they died... The commoners ... had no souls.

They were commonly referred to, even today, as the "kainanga-e-fonua" or the "eaters of the soil".

By the thirteenth century, according to legend, Tongan society consisted of a centralised system of power, in which one chief was superior to all others, had authority over the followers and derived

18 Ian C Campbell Island Kingdom: Tonga Ancient and Modern (Canterbury University Press, Christchurch, 1992) 1; Anton Ernst Oldofredi Das Südsee-Königreich Tonga (Freiburg, 1975) 41.

19 Robert W Williamson Essays in Polynesian Ethnology (Cambridge University Press, Cambridge, 1939) 206.

20 The following theory was developed by Williamson, ibid, 206-207. He relies on Handy "Problems of Polynesian Origin" (1924) 15 Bishop Museum Bulletin 7.

21 Taliai, above n 10, 79. 
his power and authority from heaven. ${ }^{22}$ Helu speaks of the time from the $8^{\text {th }}$ until the $14^{\text {th }}$ century $\mathrm{AD}$ in Tonga as a settled, centralised form and refers to this time as "pax Tongana". 23

The chiefs exercised multiple functions. ${ }^{24}$ Economically, they controlled production and land as well as the labour and tribute given to them by the people. Furthermore, the chiefs were ceremonial leaders and the people's material connection to the gods. They administered resources, carried judicial duties and kept control of inter-tribal affairs. This centralised leadership fostered a proper distribution of resources and minimised disputes. However, the people had to accept social inferiority as well as etiquette restrictions. They were obliged to supply the chief with resources and were in danger of becoming subjected to tyranny.

Around the time of the thirteenth century, the highest chief became accepted to the extent that a challenge was unacceptable. Before this change, legend has it that Tu'itâtui, the builder of the $H^{\prime} a^{\prime}$ amonga ${ }^{25}$ and eleventh Tu'i Tonga (title of the early Tongan King, while the first is said to have been the son of the god Tangaloa Eitumatupu'a ${ }^{26}$ stood with his back to a stone, "swinging a stout stick at knee level when addressing his chiefs", ${ }^{27}$ in order to protect himself from possible attacks. Over the generations, the rule of chiefs was cemented by the sanctity of chieftainship and the traditional definitions and order of ranks. Furthermore, educational as well as material inequalities favoured the position of a chiefly family in comparison to commoners. ${ }^{28}$

The resulting social structure of personal authority and rank is reflected in the modern Tongan language. It supplies the King with a separate register of speech, factually an independent language with different vocabulary, which most commoners are unable to understand. In between the regal register of the King and the ordinary register for commoners, there is an honorific register for chiefs, which mirrors the social ranks: aristocracy (hou'eiki), chiefs (mu'a eiki) and commoners $\left(t u^{\prime} a\right) .{ }^{29}$ To use the example chosen by Churchward, the ordinary word for "to eat" is kai, whereas the honorific word used in communication with chiefs and holders of high offices is 'ilo, while the regal word

22 Campbell, above n 18, 13.

23 I F Helu "Democracy bug bites Tonga" in Culture and Democracy in the South Pacific (University of the South Pacific, Suva, 1992) 139.

24 For a concise list of advantages and disadvantages for chiefs and the people see Williamson, above n 19, 208.

25 A trilithon on Tongatapu.

26 Taliai, above n 10, 79.

27 Campbell, above n 18, 9.

28 Williamson, above n 19, 208.

29 Campbell, above n 18, 8. 
used referring to a god or the king is taumafa ${ }^{30}$ This solidifies the current social structure, making it impossible to abolish without attacking cultural fundamentals. In modern Tonga, the prevalent knowledge of the English language, which is taught parallel to Tongan in high schools, may help to alleviate this effect.

A challenge of this structure by commoners seemed unlikely over a long period of time, as submissiveness and humility of the commoners became a source of identity and pride ${ }^{31}$ and extended into smaller social units. The head of a family made important decisions about marriages and land allocation, still being subordinated to a person of higher rank. This shows that the concept of rank even among commoners was such a part of the Tongan identity that acceptance of chiefs was no longer in question.

The rank of the chiefs themselves was determined by many factors among them being age, order of birth and the degree of tapu, which depended on the distance of the relationship of the chief to the first Tu'i Tonga and as such to the divinity of the god Tangaloa 'Eitumatupu'a. The status was, however, not only determined by birth-given characteristics. The mana of a chief was believed to be granted by gods and expressed the favour of the god towards the chief. It was expressed by his qualities and actions. A definition is not entirely agreed upon among scholars, but it includes a supernatural component. ${ }^{32}$ Bravery, success, intelligence, strength and wisdom among other qualities showed that the chief was favoured by the god, which in turn affected how the chief was regarded. The Tongan system incorporated the two basic ideas of leadership predominant in the Pacific - the "big man" system, which is competitive and includes choosing the leader by personal qualities and the "chiefly" system, which is based on genealogical entitlement. ${ }^{33}$ While the latter dominates the Tongan tradition, the concept of mana proves that personal qualities had a strong influence on the chief's social position.

\section{B Limits to Chiefly Power}

The traditional chiefly organisation served its purpose for some time, but between 1777 and 1820 a civil war arose as a consequence of conflicts between the chiefs. ${ }^{34}$ Ultimately, however, the ascendancy of Taufa'ahau, a Christian convert, ended these struggles. Taufa'ahau, who was baptised in 1831 as Siaosi, ${ }^{35}$ proclaimed the Vava'u Code in 1839 in Ha'apai and Vava'u, which he ruled over during that time. This code put into practice Christian rules (for example the prohibition of

30 Clerk Maxwell Churchward Tongan Grammar (Oxford University Press, London, 1953) 304.

31 Campbell, above n 18, 26.

32 Richard Feinberg "Elements of Leadership in Oceania" (2002) 12:1 Anthropological Forum 9, 15.

33 The two systems are defined in Feinberg, ibid, 11.

34 Campbell, above n 18, 37.

35 Siaosi is the Tongan form of the name George. 
work on the Sabbath), but also set an early limit to chiefly power. Judges were appointed to decide on criminal offences and the punishment thereof, which was formerly a responsibility of the chiefs. ${ }^{36}$ The Vava'u Code also included the idea of equality, as the subjects of this law were to be treated equally by the judges. ${ }^{37}$

In 1845, Taufa'ahau, from then on known as Tupou I, was proclaimed Tu'i Kanokupolu and united the power over all of Tonga in one person, establishing his supremacy 1850 with the Code of Law for all Tongans. ${ }^{38}$ This newly proclaimed Code included the prohibition of common crimes, but more importantly set limits to chiefly power. It limited political power to chiefs, who had authority to govern, while disempowering mere chiefs by birth. ${ }^{39}$ Furthermore, chiefs had to obey the same law as commoners.

In 1862, a further code of law was proclaimed. It included the Emancipation Edict, abolishing all chiefly authority over the people. The chief's right to the property of their commoners was abolished $^{40}$ so that commoners and chiefs were to have "the same legal rights in all respects". ${ }^{41}$ The Constitution followed in 1875 and swept away the last legal vestiges of traditional chieftainship by establishing a new aristocracy and thus transforming chieftainship to kingship. ${ }^{42}$ This Constitution is - in amended form - still in force today. Although chieftainship was abolished, the newly proclaimed aristocracy was composed of selected former chiefs, in an attempt to settle the ongoing conflicts over power and appease the most powerful chiefs in Tonga. ${ }^{43}$

Thus, aristocracy was established to keep the peace between the King and the former chiefs, which would have otherwise been without any authority. As outlined above, certain class differences are deeply rooted in Tongan history. The privileges of nobles in current legislation reflect these distinctions and perpetuate the traditional privileges of chiefs into Tongan's modern day aristocracy.

36 Campbell, above n 18, 64.

37 Oldofredi, above n 18, 82.

38 Taliai, above n 10, 79.

39 Campbell, above n 18, 65.

40 Ibid, 69.

41 Ibid.

42 Ibid, 78.

43 George Marcus The Nobility and the Chiefly Tradition in the Kingdom of Tonga (The Polynesian Society, Wellington, 1980) 37. 


\section{TONGA'S OBLIGATIONS TO PROTECT EQUALITY UNDER INTERNATIONAL LAW}

Having established that current Tongan legislation privileges nobles over commoners, it will be examined against which standards the different treatment of nobles and commoners is to be measured in public international law. Thus, in this section, the international human rights standard for equality, in so far it poses obligations on Tonga, will be assessed. The origin of equality as a political concept as well as the current legal situation will be illustrated. It will be shown that equality and non-discrimination are foundation stones of human rights development and bind Tonga by forming part of customary international law and ius cogens. ${ }^{44}$

The principle of equality is part of most human rights treaties. However, it is in itself an extremely broad concept, which can be applied to every possible circumstance giving rise to a different factual or theoretical treatment. In order to understand how a certain cultural fact conflicts with this concept, a more precise definition has to be established. Such a definition starts with a brief look at the roots of the concept.

\section{A Historical Background of the Concept of Equality}

The concept of equality in a legal and political sense can be traced back to antique writers and philosophers. Cicero argued in his work De Re Publica ${ }^{45}$ that liberty can only exist where it is equally available to everyone. This was reiterated by Rousseau, who elaborated on equality and distinguished two aspects of inequality: natural inequality 46 and political inequality, which "depends on a kind of convention, and is established, or at least authorised by the consent of men". 47

Traces of the evolved concept of equality can be found in all cornerstones of human rights development. ${ }^{48}$ The principle of equality has subsequently been transformed from binding only the

44 Latin for "compelling law". To norms of ius cogens no derogation is under any circumstances permitted, such norms bind all states and a modification is only possible by a subsequent norm of ius cogens. See also Vienna Convention on the Law of Treaties, Art 53.

45 Cicero De Re Publica Liber I, 47.

46 The inequality which is "established by nature, and consists in a difference of age, health, bodily strength, and the qualities of the mind or of the soul": Rousseau A Dissertation on the Origin and Foundation of the Inequality of Mankind (1754) ch 1.

47 Ibid.

48 The Magna Carta (1215) included in ch 40 the provision "to no one will we sell, to no one will we refuse or delay right or justice", referring to equal access to justice and equal protection of the law. The Déclaration des Droits de l'Homme et du Citoyen (1789) provided in Art 1 that all "men are born and remain free and equal in rights". The Virginia Bill of Rights (1776) stated in s 1 that "all men are by nature equally free and independent". Moreover, the principle of equal protection of the laws was included in the $14^{\text {th }}$ Amendment 
judiciary to a substantive guarantee that also binds the legislature. ${ }^{49}$ Thus, equality is a judicial and legislative guarantee for citizens and this interpretation of equality is deeply rooted at least within western legal tradition.

\section{B Equality Under International Law Today}

To examine the content of the notion of equality in international law, international and regional instruments of human rights protection have to be analysed. After a short overview over international instruments that protect equality, regional ones will be briefly discussed. Both international and regional instruments set the foundation for customary international law, which will be regarded in the final part of this section.

\section{International instruments of protection}

Focussing on an international norm of equality, the net of protection tends to be less intricate than for regional ones such as the European system, as there is more diversity of interests among a greater number of states and consensus is usually reached on the lowest common denominator.

\section{Universal Declaration of Human Rights}

The Universal Declaration of Human Rights (UDHR) ${ }^{50}$ establishes equality rights in Article 1: "[a]ll human beings are born free and equal in dignity and rights"; Article 2: "[e]veryone is entitled to all the rights and freedoms set forth in this Declaration, without distinction of any kind" and article 7: "[a]ll are equal before the law and are entitled without any discrimination to equal protection of the law. All are entitled to equal protection against any discrimination in violation of this Declaration..." Thus the ideas of equality before and equal protection of the law, as well as an accessory right to non-discrimination, ${ }^{51}$ are included in the UDHR.

\section{The United Nations Charter, Twin Covenants and other Conventions}

The Charter of the United Nations (UN Charter) ${ }^{52}$ itself is silent on specific human rights, since a catalogue of human rights could not be agreed upon at the time of the Charter's formation. ${ }^{53}$ Only

to the United States Constitution (1868) establishing that "no state ... shall ... deny to any person within its jurisdiction the equal protection of the laws".

49 Manfred Nowak UN Covenant on Civil and Political Rights: CCPR Commentary (Engel, Kehl, 1993) Art $26 \mathrm{n} 2$.

50 Universal Declaration on Human Rights (10 December 1948) UN Doc GA/Res/217A (III) [UDHR].

51 An accessory right is a right to non-discrimination, which is not absolute, but relative to other human rights guarantees.

52 Charter of the United Nations (26 June 1945) 1 UNTS 16.

53 Bruno Simma The Charter of the United Nations - A Commentary (2 ed, Oxford University Press, Munich, 2002) 35. 
minor links to human rights can be found, a shortcoming that was later remedied by the Twin Covenants. ${ }^{54}$ However, even in the UN Charter, despite ideological discrepancies, it was agreed to mention equality as a purpose of the Charter: ${ }^{55}$

To achieve international co-operation in ... promoting and encouraging respect for human rights and for fundamental freedoms for all without distinction as to race, sex, language, or religion. ...

The International Covenant on Civil and Political Rights (ICCPR) ${ }^{56}$ and the International Covenant on Economic, Social and Cultural Rights (ICESCR) ${ }^{57}$ also contain clauses guaranteeing equality. Article 26 of the ICCPR provides:

All persons are equal before the law and are entitled without any discrimination to equal protection of the law. In this respect, the law shall prohibit discrimination and guarantee to all persons equal and effective protection against discrimination on any ground such as race, colour, sex, language, religion, political or other opinion, national or social origin, property, birth or other status.

The provision has been construed to be a general prohibition of discrimination ${ }^{58}$ and thus effectively absorbs ICCPR article 2(1), which provides merely for an accessory right to equality. ${ }^{59}$ Article 26 of the ICCPR includes three different and distinct equality concepts: equality before the law, equal protection of the law and protection against discrimination. ${ }^{60}$

Articles 2.2 and 3 of the ICESCR contain accessory non-discrimination clauses and mention equality in a number of provisions with specific association. The principle of non-discrimination is also the underlying principle of the Convention on the Elimination of All Forms of Racial

54 The Twin Covenants are the International Covenant on Civil and Political Rights (16 December 1966) 999 UNTS 171 [ICCPR] and the International Covenant on Economic, Social and Cultural Rights (16 December 1966) 993 UNTS 3 [ICESCR].

55 Charter of the United Nations, above n 52, Art 1.3.

56 ICCPR, above n 54.

57 ICESCR, above n 54

58 CCPR General Comment 18 (1989) No 12. This has been clarified after a lengthy scholarly discussion by the United Nations Human Rights Committee in Broeks $v$ Netherlands Yearbook of the Human Rights Committee 1987 Vol. II 193 and Zwaan-de Vries v Netherlands Yearbook of the Human Rights Committee 1987 Vol. II 300. After these cases, Art 26 was treated "in isolation from the rest of the Covenant" and no longer "in conjunction with other rights of the Covenant". See Pierre-Marie Dupuy "Equality under the 1966 Covenants and in the 1948 Declaration" in Wolfrum et al Gleichheit und Nichtdiskriminierung im nationalen und internationalen Menschenrechtsschutz 165 (2003) Beiträge zum ausländischen öffentlichen Recht und Völkerrecht 149, 152.

59 Dupuy, ibid, 155.

60 See also Torkel Opsahl "Equality in Human Rights Law" Festschrift Felix Ermacora (Kehl am Rhein, ERG, NP Engel Verlag, 1988) 51-52, who calls the equality focus of the ICCPR an "overkill" in emphasis. 
Discrimination (CERD) ${ }^{61}$ and the Convention on the Elimination of All Forms of Discrimination Against Women (CEDAW), ${ }^{62}$ as well as other conventions of the UN and the International Labour Organization. ${ }^{63}$

\section{European instruments of protection}

In the latest legislative development of the concept of equality, the reach of the guarantee of equality has been increased, by expanding prohibited reasons for discrimination. An almost universal concept of non-discrimination is developing in European Union law, where the Racial Equality Directive ${ }^{64}$ and the Employment Equality Directive ${ }^{65}$ have been implemented in member states, most of them going beyond the protection demanded by the directives. ${ }^{66}$

The European Convention for the Protection of Human Rights and Fundamental Freedoms (ECHR) ${ }^{67}$ includes an accessory right to equality in Article 14, ensuring a right to nondiscriminatory treatment only in connection with the rights and freedoms of the Convention. However, the twelfth Optional Protocol to the ECHR includes a general prohibition of discrimination.

61 Convention on the Elimination of All Forms of Racial Discrimination (21 December 1965) 660 UNTS 195.

62 Convention on the Elimination of All Forms of Discrimination Against Women (18 December 1979) 1249 UNTS 13.

63 For an analysis of treaties including the principle of equality and non-discrimination see Timo Makkonen The Principle of Non-Discrimination in International Human Rights Law and EU Law (Helsinki, 2005).

64 Council Directive 2000/43/EC (29 June 2000).

65 Council Directive 2000/78/EC (27 November 2000).

66 Mark Bell and Janet Cormack Developing Anti-Discrimination Law in Europe (Migration Policy Group, Utrecht, 2005) 8. The grounds for discrimination included in the directives are racial and ethnic origin, religion and belief, age, disability and sexual orientation. Other grounds are already accepted under EU law. In addition to this broad spectrum of possible grounds for discrimination, all national laws have to be interpreted "in the light of the wording and purpose of the Directive" (Case 14/83, Von Colson and Kamann $v$ Land Nordrhein-Westfalen [1984] ECR 1891) by national courts. This trend to increasingly effective protection against inequalities has departed from the former basis of eliminating the supremacy of one class for the common good. Equality is now enforced in a finely spun web of discriminatory grounds and methods. This is problematic on its own, as the finer equality is applied, the higher the sensibility for remaining inequalities is, so that the principle's application in itself carries a danger of trivialisation. Michael Stolleis "Historische und ideengeschichtliche Entwicklung des Gleichheitssatzes" in Wolfrum et al, above n 58, 21.

67 European Convention on Human Rights (4 November 1950) 213 UNTS 222. 


\section{Other Regional Instruments of Protection}

The American Convention on Human Rights (ACHR) ${ }^{68}$ states: "[a]ll persons are equal before the law. Consequently, they are entitled, without discrimination, to equal protection of the law."69 Equality also is ensured for specific circumstances in Articles 8(2), 17(4), 17(5), 23(1.b) and 23(1.c). The guarantee of equality in the ACHR is not limited to an accessory guarantee. The African Charter on Human and People's Rights, ${ }^{70}$ also known as the Banjul Charter, echoes Article 24 ACHR in Article 3 and introduces in Article 2 an accessory right to equality, binding equality to the "rights and freedoms recognized and guaranteed in the present Charter". Furthermore, it includes an open catalogue of prohibited grounds for discrimination, including "national and social origin," "birth" and "other status". The not yet binding Charter of the Arab League 1945 also includes a similar provision establishing an accessory right to equality in Article 2. In Article 9, it guarantees equality before the law and a right to legal remedy. In addition, it mentions equality in the Preamble and in Article 32 guaranteeing equality of opportunity "in regard to work".

\section{Customary International Law and Ius Cogens}

It has been shown that there is a universal acceptance of equality, which transcends ideological barriers, as can be seen by its implementation in all regional human rights treaties. Moreover, it has been shown that it forms part of all comprehensive international human rights treaties. This is a strong suggestion for customary international law. In the following this status will be confirmed.

Although the UDHR was intended to be a declaration which "does not purport to be a statement of law or of legal obligation", ${ }^{71}$ there is a tendency to give legal character to several of its provisions. ${ }^{72}$ The Montreal Assembly for Human Rights promoted as early as 1968 that the UDHR "constitutes an authoritative interpretation of the Charter of the highest order, and has over the years become a part of customary international law",73 Customary international law includes general principles of law, which are carried by an equal pattern of state practice and accepted as customary international law by opinio juris. ${ }^{74}$ It binds all states whether or not they accepted an obligation. ${ }^{75}$

68 American Convention on Human Rights (22 November 1969) 1144 UNTS 143.

69 Ibid, Art 24.

70 African Charter of Human Rights (27 June 1981) 1520 UNTS 217.

71 Statement of United States representative at the time of UDHR adoption, reprinted in Lori F Damrosch et al International Law (West Publishing, St. Paul, 2001) 593.

72 Ibid, 594.

73 "Montreal Statement of the Assembly for Human Rights 2" reprinted in (1968) 9:1 Journal of the International Commission of Jurists 94, 95.

74 Latin for "opinion of law"; ICJ Statute Art 38 (1.b); North Sea Continental Shelf Case ICJ Reports (1969) 3 , No 71. 
While there is still scholarly disagreement on the extent to which the UDHR constitutes customary international law, ${ }^{76}$ the right of equality, as laid down in Article 2 of the UDHR forms part of that body of law and what is more can be considered to be ius cogens. This has been confirmed by the Inter-American Court of Human Rights in unequivocal terms: ${ }^{77}$

This Court considers that the principle of equality before the law, equal protection before the law and non-discrimination belongs to ius cogens, because the whole legal structure of national and international public order rests on it and it is a fundamental principle that permeates all laws. Nowadays, no legal act that is in conflict with this fundamental principle is acceptable, and discriminatory treatment of any person, owing to ... social origin ... civil status, birth or any other status is unacceptable. ... At the existing stage of the development of international law, the fundamental principle of equality and nondiscrimination has entered the realm of ius cogens.

The ius cogens character is especially true for discrimination based on social class and birth including the distinction between nobles and commoners before the law, as there is an overwhelming uniformity in state practice accepting this as unlawful discrimination. Furthermore, it is at the core of equality, which dates back to the $18^{\text {th }}$ century and has originally been "a hallmark of bourgeois thought... against privileges of nobility". ${ }^{78}$ Equal protection of the law and equality before the law, especially in a social class discrimination context, is, as Article 53 of the Vienna Convention on the Law of Treaties ${ }^{79}$ describes, a "peremptory norms of general international law." To a norm of ius cogens "no derogation is permitted and [it] can be modified only by a subsequent norm of general international law having the same character". ${ }^{80}$

The equality aspects in question in Tonga are associated with other rights recognised under international law, such as the right of people to change their government, ${ }^{81}$ the right to own property, ${ }^{82}$ and the right to protection of one's honour. ${ }^{83}$ Thus, even if the ius cogens norm is

75 North Sea Continental Shelf Case, ibid.

76 See Hailbronner in Vizthum et al Völkerrecht (Springer, Berlin, 2007) 231.

77 "Juridical Condition and Rights of the Undocumented Migrants" Advisory Opinion OC-18/03 (17 September 2003) Inter-American Court of Human Rights Ser. A 18 (2003) para 101; see also Maya Indigenous Community Case Inter-American Commission 12.053 para 4.

78 Opsahl, above n 60, 51.

79 Vienna Convention on the Law of Treaties (27 January 1980) 1155 UNTS 33.

80 Ibid, Art 53.

81 See the privileges of nobles with regard to electing the King and the equal number of representatives for both classes, leading to an imbalance of power in favour of the nobles.

82 See the factual differences for land ownership.

83 See the differential protection in the Defamation Act. 
merely an accessory right to equality - which one might argue with reference to lack of uniform state practice evidenced by state protest ${ }^{84}$ against the broad interpretation of Article 26 of the ICCPR by the United Nations Human Rights Committee ${ }^{85}$ - it would be infringed by discriminatory treatment with regard to those rights.

\section{$V$ THE EFFECT OF THESE PROVISIONS ON TONGA}

It has been set out above that equality as a human right is protected by the United Nations. In fact, it has been stated that the "United Nations Organization had been founded principally to combat discrimination in the world". 86 Tonga joined the UN as a member state in 1999 and as such accepted the UN Charter and its purposes. A main purpose outlined in the UN Charter is the protection of human rights. Articles 1.3, 55(c) and 56 discuss this purpose and make explicit mention to the principle of equality. Moreover, the Charter sets out the UN's aim to "promote and encourage respect for human rights and fundamental freedoms for all without distinction as to race, sex, language or religion". 87

Furthermore, when Tonga was already a member of the UN, the Millennium Declaration ${ }^{88}$ was adopted by the UN General Assembly, affirming the aim of the organisation and its member states to adhere to human rights. However, the Millennium Declaration is not binding and imposes no direct legal obligation on the declaring states. The UN Charter, which is binding, does not explicitly outlaw discrimination on the basis of social status or birth. Tonga is neither a member of the ICCPR nor the ICESCR. Thus Tonga is not legally bound by any human rights treaty expressly giving the right of equality. However Tonga is bound - as is every state - by customary international law and ius cogens. It has been established that equality before the law and a right to non-discrimination based on social class and birth belong to this body of law.

A right to equality "does not make all differences of treatment discriminatory. A differentiation based on reasonable and objective criteria does not amount to prohibited discrimination" 89 where the aim pursued in drawing the distinction is legitimate and the means employed are not disproportionate. ${ }^{90}$ Upholding traditional and cultural values may be a legitimate aim of the Tongan

84 See for example the (inadmissible) reservation of Germany in BGBl. 1994 II, 311 and the reservation by Switzerland in BGBl. 1993 II, 1998 (1999).

85 See CCPR General Comment 18, above n 58.

86 UN Doc A/C 3/ S.R 100, 7, cited in Warwick McKean Equality and Discrimination under International Law (Oxford University Press, Oxford, 1983) 59.

87 UN Charter Arts 1.3 and 13.1.b.

88 United Nations Millennium Declaration (8 September 2000) UN Doc. A/Res/55/2 (2000).

89 Opsahl, above n 60, 62; see also Li Weiwei Equality and Non-Discrimination under International Human Rights Law (Ad Notam Gyldendal, Oslo, 2004) 9.

90 Opsahl, above n 60, 55. 
legislation. However the perpetuation of class distinction directly contradicts the equality principle. As such, there is no underlying legitimate aim for the legislation outlined above. The legislation privileging nobles is discriminatory and thus in contradiction to international law.

Having established that Tonga is bound by a ius cogens norm protecting equality, which it infringes by perpetuating class privileges, Tonga's obligations to remedy this situation must be examined. There is agreement that a state whose legislation is incompatible with binding international law is under an obligation to perform legislative acts that remedy such an incompatibility. ${ }^{91}$ Thus, Tonga is obliged to change the discriminatory legislation and reform its system.

Moreover, ius cogens norms result in obligations erga omnes, ${ }^{92}$ which means that the obligation is incurred towards all states and non-compliance with these norms can be challenged by every subject of public international law, regardless of a pre-existing treaty obligation. ${ }^{93}$ Furthermore, the obligation is not limited to abolishing existing discriminatory legislation, but includes specific (affirmative) action to ensure future equality. ${ }^{94}$

\section{CONCLUSION}

Tongan legislation and social structure feature discriminatory inequalities, as is typical for stratified chiefdom societies. Thus, "Tongan culture clashes head-on with basic human rights requirements" 95 because "as far as Tongan culture is concerned human beings are never born equal in dignity and rights because national and social origin, birth and wealth all feature in the social calculus that determines one's status...". ${ }^{96}$ However, duties under ius cogens have to be followed, even when they conflict with national laws. ${ }^{97}$

How can this conflict be resolved? Will we rekindle the criticism against globally equal human rights standards as Western ideas and launch over Tonga a new mission, this time not Christian, but based on human rights? We will have to take into consideration that a culture has a certain intrinsic

91 Stephan Hobe and Otto Kimminich Einführung in das Völkerrecht (8 ed, A. Francke, Tübingen, 2004$) 225$ $-227$.

92 Latin for "towards everyone".

93 Barcelona Traction, Light and Power Co Ltd (New Application) (Belgium v Spain) 1970 ICJ Rep 4 (Judgment 5 February 1970); [1976] 2 YB International Law Commission pt 2, 99, UN Doc. A/CN.4/SER.A/1976/Add.1 (pt.2); Hobe and Kimminich, above n 91, 174.

94 Nowak, above n 49; Opsahl, above n 60, 57-58; CCPR General Comment 3; CESR General Comment 3.

95 Helu, above n 8, 33.

96 Ibid, 35.

97 Georg Dahm et al Völkerrecht, Band 1,1, Die Grundlagen. Die Völkerrechtssubjekte (Walter de Gruyter, Berlin, 1989) 103. 
value. It is one of humanity's greatest treasures to have diverse cultures and therewith an array of different ways of managing the common challenges of the environment and the everyday fight for survival. This diversity has to be upheld.

A danger of the growing influence of international law is that it severely alters cultures and traditions in order to achieve the goal of universal rights. The originality of indigenous cultures, traditions and multifaceted lore has to be approached with caution, as contact will inevitably alter them severely. On the other hand, we cannot uphold the value of a culture at the cost of fundamental concepts that should be applicable to everyone. The right of progress cannot be denied to these cultures, as this would mean to make the people of Tonga, who increasingly call for democracy and human rights, ${ }^{98}$ mere objects in a bizarre museum of ethnology. It has been stated in connection with the Constitutional Convention that: ${ }^{99}$

The overall effect [of the current legal system] is that Tonga has a class system in which the interests of the elite take precedence over those of the bulk of the population. The explanation given by those who support the status quo is that Tonga has survived because it has had the same system for over a thousand years. ... Under the guise of respect for traditions and the culture, those who benefit from the system turn a blind eye to corruption, nepotism, selfishness and favouritism.

There is a difficult balance to maintain between preserving cultural traditions while universalising human rights, which are rooted in the inherent dignity of the human being. The situation can be compared to that of a strategic survival game. Each player - much like each government - has different tactics, and makes independent choices that they deem right and fitting. Yet all have to abide by the same rules, which may limit them in their individuality, but also ensure that the game remains operable and enjoyable to all.

The Tongan Government and ultimately its monarch are under an international legal obligation to provide for equality among the people of Tonga. It will be a significant task to reform the system, as it affects not only political rights but also social status and everyday life. This is where the individuality of one society begins and where the rules of the game end. The goal of equal rights and a society without a legally privileged class may also be achieved in a monarchy such as Tonga, especially since Tonga has taken significant steps towards more democracy in this current system. Ultimately, it will be the role of the Tongans and their progressive and conservative thinkers to selfdetermine their political future and to decide if the monarchy should be upheld, maybe in a reduced form, or if a totally new and more democratic system has to be sought. More democratic systems may also find a solid foundation in traditional Tongan concepts. Essentially, democracy will mean

98 This is evidenced by the Convention on Tongan Constitution and Democracy (1992) and the political speeches of the Human Rights and Democracy movement, whose candidates' agenda is to reform the system.

99 Constitutional Convention, Appendix II, 157. See, above n 4, for full report. 
turning away from choosing leaders by birth and bloodlines, while turning to choosing leaders by the ancient concept of mana, meaning the choice of leaders by their qualities, such as bravery, intelligence, wisdom and success and by their actions.

Concerning reforms, there is no lack of suggestions, as the Constitutional Convention has shown. In this Convention and subsequently in the drafts of the Basic Proposals for an alternative Structure of Government for Tonga ${ }^{100}$ sensitive suggestions have been made on how to balance culture and human rights. It is of great value that these suggestions come from within Tonga and they should be held in high esteem and deserve a great deal of attention. Tonga's overall cooperative stand towards human rights, ${ }^{101}$ the recent proclamation by Tupou $\mathrm{V}$, in which he consents to reform the monarch's powers in favour of a more representative parliament ${ }^{102}$ and the planning of a new Constitutional Convention ${ }^{103}$ mark important steps towards reforms as suggested by the people.

100 Available at www.planet-tonga.com/HRDMT/Articles/HRDMT_Proposal/Proposal-English.shtml (accessed 23 December 2008).

101 As witnessed by the fact that Tonga was the first Pacific Island state to successfully complete the Universal Periodic Review of the Human Rights Council, which started in April 2008. See UN Doc A/HRC/8/48 (5 June 2008).

102 Declaration from the Office of the Prime Minister Nuku'alofa, above n 9.

103 www.pmo.gov.to/featured-news-multimedia-175/171-tongan-constitutional-convention-in-2009.html (accessed 24 December 2008). 